\title{
Quality characteristics of garlic peel according to processing methods
}

\author{
Ji Hyun Min*, Jae Hyun Jeong, Young Uk Park, Jae Sun Lee, \\ Seong Ju Lee, Who-Bong Chang \\ Chungbuk Agricultural Research and Extension Services, Cheongju 28130, Korea
}

\section{가공방법에 따른 마늘껍질의 품질 특성 \\ 민지현*·정재현 · 박영욱·이재선 · 이승주·장후봉 \\ 충청북도농업기술원}

\begin{abstract}
Garlic peel has been found to have various beneficial effects including antioxidant activities, antithrombosis activities and cancer inhibition. This study was to analyze the quality characteristics and antioxidant activities of garlic peel processed using different methods (control, roasting, steaming, roasting after steaming and blanching) to determine the most appropriate processing method for garlic peel to be used as a functional food ingredient. The lightness color values was highest in the control group, redness was highest in the roasting after steaming group, and yellowness was highest in the roasting group. The total pyruvate content of the roasting after steaming group garlic peel was $37.05 \mathrm{mg} / 100 \mathrm{~g}$, which was higher than those of the other groups. The total polyphenol and total flavonoid contents of garlic peel ranged 47.60 to $172.53 \mathrm{mg} / 100 \mathrm{~g}$ and 3.43 to $17.63 \mathrm{mg} / 100 \mathrm{~g}$, respectively. The highest total polyphenol content and total flavonoid content were observed for the roasting after steaming group. 2,2-Diphenyl-1-picrylhydrazyl radical scavenging activity was also the highest in the roasting after steaming group (81.28\%). These results indicate that the method used to process garlic peel affects its quality, and that roasting after steaming is the most appropriate processing method, as it achieves the highest antioxidant activity.
\end{abstract}

Key words : garlic peel, processing, quality characteristics, total polyphenol, DPPH radical scavenging activity

\begin{abstract}
서 론
마늘(Garlic)은 백합과(Lilliaceae) 알리움속(Allium) 식물 로 예로부터 조미료, 향신료 및 의약품으로 이용되어 왔다. 마늘은 항암효과(Kim 등, 2006), 항균작용(Choi, 2001), 항 산화 효과(Kim 등, 2010), 고혈압 예방 및 혈압 강하(Ruffin 과 Hunter, 1983; Banerjee와 Maulik, 2002), 콜레스테롤 저 하(Sharma와 Sharma, 1979)와 같은 기능이 있다고 알려져 있다. 마늘의 이런 기능은 알리신을 비롯한 다양한 황화합 물에서 기인하는 것으로 알려져 있으며(Koch와 Lawson, 1996), 이 때문에 마늘은 건강기능식품으로도 널리 이용되
\end{abstract}

고 있다. 마늘을 이용한 가공식품 개발을 위해 다양한 연구 가 시도되었으며 마늘을 첨가한 젤리, 잼 등 많은 제품들이 개발되고 있다.

마늘의 잎은 풋마늘로, 마늘종은 장아찌 등 절임용으로 사용되지만 수확 후 다른 부산물은 버려지고 있는 실정이 다. 통계청(2009)에 따르면 마늘 생산물 중 부산물이 차지 하는 비율은 $2.65 \%$ 정도이고, 2019년 마늘 생산량이 약 387,671 톤인 것을 고려할 때, 부산물은 약 10,273 톤 정도로 예상되며, 폐기되는 마늘껍질의 양도 상당할 것으로 생각 된다. 그러나 마늘껍질은 인편에 비해 총 폴리페놀 함량은 약 7 배, 항산화 활성인 DPPH radical scavenging activities는

*Corresponding author. E-mail : minjh121@korea.kr, Phone : +82-43-220-5842, Fax : +82-43-220-5839

Received 11 November 2019; Revised 05 December 2019; Accepted 05 December 2019.

Copyright (c) The Korean Society of Food Preservation.

This is an Open Access article distributed under the terms of the Creative Commons Attribution Non-Commercial License (http://creativecommons.org/licenses/by-nc/4.0) which permits unrestricted non-commercial use, distribution, and reproduction in any medium, provided the original work is properly cited. 
약 1.5 배 높다고 보고되어 있으며(Nuutila 등, 2003), 총 플라보노이드 함량은 약 3배 정도 높다(Shin과 Kim, 2004a) 고 알려져 있다. 또한, 마늘 껍질 추출물은 항산화 효과뿐 만 아니라 간암, 유방암 등 4종의 암세포 증식 억제 활성 (Son, 2017), 체내 지질 감소 및 항혈전 효과(Shin과 Kim, 2004b)와 같은 기능이 있다고 보고되었다. 이처럼 마늘껍 질은 인편 못지않은 기능성 성분을 함유하고 있어 기능성 소재로 활용가치가 높은 부산물이다.

지금까지 자몽껍질(Ko 등, 2014), 유자과피(Chung 등, 2019), 메밀껍질(Im 등, 2016), 양파껍질(Ma 등, 2019) 등등 의 농산부산물을 활용한 연구가 수행되어왔으며, 부산물 을 이용한 음료, 소스 개발 등이 이루어지고 있다. 마늘껍 질도 우수한 생리활성이 알려져 가정에서 마늘껍질을 활 용하여 육수, 차 등으로 섭취를 하고 있으나, 마늘껍질 가공 및 전처리에 관한 연구는 미비한 실정으로 이에 관한 연구가 필요한 실정이다.

이에 본 연구에서는 버려지고 있는 고기능성 마늘껍질 의 이용가치를 향상시키고자 증숙, 볶음 등의 방법으로 마늘껍질을 가공처리하여 추출물을 제조한 후 각 추출물 의 항산화 활성을 조사하여 효과적인 가공방법을 제시하 고, 기능성 음료 등 식품 소재로 활용하기 위한 기초자료를 제공하고자 연구를 수행하였다.

\section{재료 및 방법}

\section{실험재료}

마늘껍질은 충청북도농업기술원 마늘연구소에서 재 배된 홍산 품종을 사용하였는데, 겉껍질은 유백색이고 알리신 및 항산화 성분이 높다고 알려진 마늘이다. 마늘껍 질은 박피한 후 깨끗이 세척하여 자연건조한 껍질을 사용 하였다.

\section{일반성분 분석}

일반성분 분석은 $\mathrm{AOAC}(1995)$ 방법에 준하여 실시하였 는데, 수분함량은 $105^{\circ} \mathrm{C}$ 상압가열건조법으로, 조단백질 함량은 Kjeldahl법, 조지방 함량은 Soxhlet 추출법, 회분 함량은 $550^{\circ} \mathrm{C}$ 회화로를 이용한 직접회화법으로 분석하였 다. 탄수화물 함량은 시료 $100 \mathrm{~g}$ 중 수분, 조단백질, 조지방, 회분 함량을 감하여 얻은 값으로 환산하였다.

\section{마늘껍질의 처리 방법}

시험에 사용된 마늘껍질은 가공 처리를 하지 않은 껍질 을 대조구로 하였으며, 그 외 마늘껍질의 가공 처리는 4 가 지 방법으로 하였는데, 30 분 볶음, 60 분 증숙, 60 분 증숙 후 30 분 볶음, 데침 방법으로 제조하였다. 볶음처리는 가마 솥냄비(Namsun marble coating, Namsun Co., Incheon,
Korea)를 이용하여 $100^{\circ} \mathrm{C}$ 에 10 분 볶은 뒤 $75^{\circ} \mathrm{C}$ 로 온도를 낮춰 볶아주었다. 증숙처리는 찜솥 겸용 가마솥냄비 (Namsun marble coating, Namsun Co., Incheon, Korea)를 이용하여 물이 끓은 후 60 분 증숙하였으며, 증숙 시 온도는 $92 \pm 2^{\circ} \mathrm{C}$ 정도로 유지하였다. 데침처리는 같은 냄비를 이용 하여 끓는물 $\left(98 \pm 1^{\circ} \mathrm{C}\right)$ 에 10 분간 데친 후 사용하였다. 모든 시료는 자연건조하여 수분을 제거한 뒤 사용하였으며, 이 때 건조된 마늘껍질의 수분함량은 $10.67-11.07 \%$ 정도였 으며, 처리방법에 따른 유의성은 없었다.

\section{분석 시료 추출}

가공 처리한 껍질을 커피분쇄기(Coffee grinder, SP7426, Supreme Electric Manufacture Co., Ltd, Guangzhou, China)를 이용하여 곱게 분쇄한 다음 증류수를 시료량의 20 배를 첨가한 후 $80^{\circ} \mathrm{C}$ 항온수조에서 3시간 동안 $250 \mathrm{rpm}$ 으로 진탕하여 분석시료를 추출하였다. 각각의 추출물은 $3,600 \mathrm{rpm}, 4^{\circ} \mathrm{C}$ 에서 10 분 동안 원심분리한 후 거름종이(No. 6, Advantec, Toyo Roshi Kaisha, Ltd., Tokyo, Japan) 1장을 깔고 감압여과(Vacuum Pump, DOA-P704-AC, GAST Manufacturing, Inc., Benton Harbor, Mi, USA) 하였다.

\section{색도측정}

각 시료의 색도측정은 분광측색계(Spectrophotometer CM-700d, Konica Minolta, Tokyo, Japan)를 이용하여 Hunter L값(명도), a값(적색도), b값(황색도)을 측정하였 으며, 각 시료당 3회 반복 측정한 후 평균값으로 나타내 었다.

\section{피루브산 함량}

피루브산 함량은 Schwimmer 등(1961)의 방법을 변형하 여 시료액 $0.1 \mathrm{~mL}$ 에 $0.0125 \%$ dinitrophenyl-hydrazine (Sigma-Aldrich Co., St. Louis, MO, USA) $3 \mathrm{~mL}$ 를 가하여 혼합한 다음 $37^{\circ} \mathrm{C}$ 에서 10 분간 반응시키고 $1.0 \mathrm{~N} \mathrm{NaOH}$ 용액 $8 \mathrm{~mL}$ 를 첨가한 후 $485 \mathrm{~nm}$ 에서 흡광도를 측정하였다. Sodium pyruvate(Sigma-Aldrich Co.)를 표준물질로 하여 얻 은 검량선으로부터 피루브산의 함량을 계산하였다.

\section{총 폴리페놀 함량}

총 폴리페놀화합물의 함량은 Folin-Denis법(Betterridge, 1981)에 따라 각 시료액 $0.1 \mathrm{~mL}$ 에 증류수 $8.4 \mathrm{~mL}, 2 \mathrm{~N}$ Folin-Ciocalteu 시약(Sigma-Aldrich Co., St. Louis, MO, USA) $0.5 \mathrm{~mL}$ 및 $20 \% \mathrm{Na}_{2} \mathrm{CO}_{3}$ 용액을 $1 \mathrm{~mL}$ 씩 차례로 가한 다음 실온에서 1 시간 정치한 후 $725 \mathrm{~nm}$ 에서 흡광도를 측정 하였다. 표준물질로 gallic acid(Sigma-Aldrich Co.)를 사용하 여 얻은 표준 검량선으로부터 추출물의 총 페놀 함량을 산출하였다. 


\section{총 플라보노이드 함량}

총 플라보노이드는 Moreno 등(2000)의 방법에 따라 시 료액 $0.5 \mathrm{~mL}$ 에 $10 \%$ aluminum nitrate $0.1 \mathrm{~mL}, 1 \mathrm{M}$ potassium acetate $0.1 \mathrm{~mL}$, ethanol $1.5 \mathrm{~mL}$ 및 증류수 $2.8 \mathrm{~mL}$ 를 차례로 가하여 혼합하고 실온에서 40 분간 정치한 다음 $415 \mathrm{~nm}$ 에 서 흡광도를 측정하였다. Quercetin(Sigma-Aldrich Co.)을 표준물질로 하여 얻은 표준 검량선으로부터 추출물의 총 플라보노이드 함량을 계산하였다.

\section{$\mathrm{DPPH}$ 라디칼 소거활성}

$\mathrm{DPPH}$ (2,2-diphenyl-1-picrylhydrazyl) 라디칼 소거활성 은 Blios(1958)의 방법을 변형하여 $\mathrm{DPPH}$ 에 대한 전자공여 효과로 각 시료의 환원력을 측정하였다. 각 시료액 0.4 $\mathrm{mL}$ 에 $0.4 \mathrm{mM} \mathrm{DPPH}$ 용액 $1.6 \mathrm{~mL}$ 를 넣고 교반한 후 30 분 방치한 다음 $525 \mathrm{~nm}$ 에서 흡광도를 측정하였다. DPPH 라 디칼 소거활성은 시료 첨가구와 무첨가구의 흡광도를 측 정하여 다음과 같이 백분율로 나타내었다.

$\mathrm{DPPH}$ 라디칼 소거활성(\%)

$=[1-($ 실험구의 흡광도/대조구의 흡광도 $)] \times 100$

\section{통계처리}

모든 분석은 3 회 반복 실험하였으며, 실험결과의 통계 분석은 CoStat(CoHort software, Berkeley, USA) 통계프로 그램을 이용하여 평균과 표준편차를 구하였고, Duncan's multiple range test $(\mathrm{p}<0.05)$ 로 유의성을 검정하였다.

\section{결과 및 고찰}

\section{일반성분}

마늘껍질의 일반성분 함량은 Table 1과 같다. 수분 함량 은 $10.97 \%$, 조단백 함량은 $3.39 \%$, 조지방 함량은 $0.39 \%$,
Table 1. Proximate compositions of garlic peel

\begin{tabular}{cc}
\hline Nutrients & Contents $(\mathrm{g} / 100 \mathrm{~g})$ \\
\hline Moisture & $10.97 \pm 2.54^{1)}$ \\
Crude protein & $3.39 \pm 0.41$ \\
Crude fat & $0.56 \pm 0.05$ \\
Crude ash & $5.83 \pm 0.87$ \\
Carbohydrate & $79.25 \pm 3.77$ \\
\hline
\end{tabular}

${ }^{1)}$ Values are mean \pm SD.

회분의 함량은 $5.83 \%$, 탄수화물 함량은 $79.25 \%$ 로 나타났 다. $\mathrm{Kim}$ 등(2010)은 마늘껍질의 조단백 함량은 $1.97 \%$, 조 지방 함량은 $1.26 \%$, 회분의 함량은 $5.23 \%$ 라고 보고하여 본 실험의 결과와 비교하여 볼 때 조단백, 조지방 함량은 차이를 보였는데, 이는 수분 함량 및 품종, 기후 등 재배환 경에 의한 차이로 생각된다.

\section{마늘껍질의 색도}

가공방법을 달리한 마늘껍질의 색도를 측정한 결과는 Table 2와 같다. 밝은 정도를 나타내는 L 값은 대조구가 74.15 로 가장 높았으며, 데침 처리한 껍질이 61.96 으로 가 장 낮게 나타났다. 전반적으로 가공공정을 거치면서 명도 는 낮아지는 경향이었다. 적색도(a값)는 증숙, 건조 후 볶 음 처리구에서 0.23 으로 가장 높았으며, 데침 처리구에서 - 1.37 로 가장 낮게 나타나 다른 처리구에 비해 녹색에 가까웠다. 황색도(b값)에서도 데침 처리구가 11.17 로 가장 낮은 값을 나타내었으며, 30 분 볶음 처리구의 황색도는 14.24 로 가장 높은 값을 나타냈다. 전체적으로 볶음 처리구 에서 13.42-14.24로 다른 처리구에 비해 유의적으로 높게 나타났는데 이는 볶음 처리 후에 황색도가 증가하는 경향 을 보였다고 한 Kwon(2014)의 결과와 비슷한 경향을 보였

Table 2. Hunter's color value of garlic peel treated by roasting, steaming, roasting after steaming, and blanching

\begin{tabular}{cccc}
\hline & & Hunter's color value \\
\cline { 2 - 4 } Sample & $\begin{array}{c}\mathrm{L} \\
\text { (Lightness) }\end{array}$ & $\begin{array}{c}\mathrm{a} \\
\text { (Redness) }\end{array}$ & (Yellowness) \\
\hline Control & $\left.74.15 \pm 0.48^{1) \mathrm{a} 2}\right)$ & $-1.05 \pm 0.19^{\mathrm{bc}}$ & $11.59 \pm 0.21^{\mathrm{d}}$ \\
Roasting & $71.15 \pm 1.23^{\mathrm{b}}$ & $-0.80 \pm 0.25^{\mathrm{b}}$ & $14.24 \pm 0.07^{\mathrm{a}}$ \\
Steaming & $69.68 \pm 0.85^{\mathrm{b}}$ & $0.18 \pm 0.22^{\mathrm{a}}$ & $12.45 \pm 0.24^{\mathrm{c}}$ \\
Roasting after steaming & $65.07 \pm 0.36^{\mathrm{c}}$ & $0.23 \pm 0.09^{\mathrm{a}}$ & $13.42 \pm 0.26^{\mathrm{b}}$ \\
Blanching & $61.96 \pm 0.30^{\mathrm{d}}$ & $-1.37 \pm 0.18^{\mathrm{c}}$ & $11.17 \pm 0.33^{\mathrm{d}}$ \\
\hline
\end{tabular}

\footnotetext{
${ }^{1)}$ Values are mean $\pm \mathrm{SD}$.
}

${ }^{2)}$ Means with different letters in the same column are significantly different by Duncan's multiple range test $(\mathrm{p}<0.05)$. 
다. 이는 볶는 과정에서 화학적 반응으로 인한 maillard 갈변반응에 의해 황색도가 증가된 것으로 생각된다.

\section{피루브산 함량}

마늘의 pyruvate는 alliin이 물리적인 손상을 받게 되면 alliinase라는 효소에 의하여 allicin과 pyruvate 및 ammonia 등 황화합물로 분해되면서 생성된다(Miron 등, 2002). Allicin은 마늘의 독특한 향미 성분으로 마늘의 중요한 품 질지표로 사용되지만 휘발성이 강하며 매우 불안정한 상 태로 존재하기 때문에 안정적인 분해산물인 pyruvate 및 ammonia 함량을 마늘 품질의 간접적인 척도로 측정하고 있다(Chung 등, 2019). Pyruvate 함량을 분석한 결과는 Table 3 과 같다. Hwang 등(2004)의 연구에서 Alliin을 함유한 마늘 은 상온보다 높은 온도에서 저장하거나 조리할 경우 pyruvate의 함량이 더 증가한다고 보고되어 있는데, 마늘껍 질에서도 대조구의 pyruvate 함량은 $6.25 \mathrm{mg} / 100 \mathrm{~g}$ 이었으 나, 열처리 과정을 거치면서 증가하는 것으로 나타났다. 볶음 처리구에서 pyruvate 함량이 $32.74 \mathrm{mg} / 100 \mathrm{~g}$, 증숙 후 볶음 처리구에서 $37.05 \mathrm{mg} / 100 \mathrm{~g}$ 으로 볶는 공정을 거치 면서 큰 폭으로 증가하였는데 이는 볶는 공정 중 alliin의 분해가 더 촉진된 것으로 추정할 수 있다. 또한, $\mathrm{Kim}$ 등 (2015), Shin 등(2008)의 연구에서 마늘이 고온에서 숙성과 정을 거치면서 마늘에 함유된 당이 분해됨에 따라 pyruvate 함량이 증가한 것으로 유추하였는데, 마늘껍질 또한 볶음 공정을 거치면서 고온에 의해 마늘껍질에 함유된 당이 분 해되어 pyruvate 함량이 증가한 것으로 유추해 볼 수 있다.

\section{총 폴리페놀 및 총 플라보노이드 함량}

총 폴리페놀 함량은 Folin-Ciocalteu phenol reagent가 추 출물의 폴리페놀성 화합물에 의해 환원된 결과, 몰리브덴 청색으로 발색하는 것을 원리로 분석하는 방식이다. 마늘 껍질 추출물의 총 폴리페놀 함량은 Table 4와 같다. 증숙 후 볶음 처리구와 30 분 볶음 처리구의 총 폴리페놀의 함량

Table 3. Total pyruvate contents of garlic peel treated by roasting, steaming, roasting after steaming, and blanching

\begin{tabular}{cc}
\hline Processing method & Total pyruvate (\%) \\
\hline Control & $6.25 \pm 0.08^{1 \mathrm{~d} d}$ ) \\
Roasting & $32.74 \pm 1.86^{\mathrm{b}}$ \\
Steaming & $8.07 \pm 0.14^{\mathrm{cd}}$ \\
Roasting after Steaming & $37.05 \pm 0.37^{\mathrm{a}}$ \\
Blanching & $8.85 \pm 1.26^{\mathrm{c}}$ \\
\hline${ }^{1)}$ Values are mean \pm SD. \\
${ }^{2)}$ Means with different letters in the same column are significantly \\
different by Duncan's multiple range test $(\mathrm{p}<0.05)$.
\end{tabular}

Table 4. Total polyphenol and total flavonoid contents of garlic peel treated by roasting, steaming, roasting after steaming, and blanching

\begin{tabular}{ccc}
\hline Processing method & $\begin{array}{c}\text { Total polyphenol } \\
(\mathrm{mg} / 100 \mathrm{~g})\end{array}$ & $\begin{array}{c}\text { Total flavonoid } \\
(\mathrm{mg} / 100 \mathrm{~g})\end{array}$ \\
\hline Control & $\left.57.77 \pm 3.09^{1) \mathrm{c} 2}\right)$ & $3.68 \pm 0.32^{\mathrm{d}}$ \\
Roasting & $109.00 \pm 1.67^{\mathrm{b}}$ & $11.05 \pm 0.07^{\mathrm{b}}$ \\
Steaming & $60.84 \pm 2.10^{\mathrm{c}}$ & $6.69 \pm 0.14^{\mathrm{c}}$ \\
Roasting after steaming & $172.53 \pm 2.22^{\mathrm{a}}$ & $17.63 \pm 0.18^{\mathrm{a}}$ \\
Blanching & $47.60 \pm 1.10^{\mathrm{d}}$ & $3.43 \pm 0.40^{\mathrm{d}}$ \\
\hline
\end{tabular}

${ }^{1)}$ Values are mean \pm SD.

${ }^{2)}$ Means with different letters in the same column are significantly different by Duncan's multiple range test $(p<0.05)$.

은 각각 $172.53 \mathrm{mg} / 100 \mathrm{~g}, 109.00 \mathrm{mg} / 100 \mathrm{~g}$ 으로 대조구 $57.77 \mathrm{mg} / 100 \mathrm{~g}$ 보다 각각 약 3.0 배, 약 1.9 배 높은 함량을 보여, 볶음 공정을 거친 처리구에서 총 폴리페놀 함량이 유의적으로 증가하는 것으로 나타났다. 이처럼 볶음 공정 을 통해 총 폴리페놀 함량이 증가하는 것은 Maillard 반응 에 의해 생성되는 중간생성물인 melanoidin에 의한 것으로 판단되며, Song 등(2013)의 연구에서 팥을 볶음처리하는 과정에서 페놀성 화합물의 함량이 증가하였다고 보고한 결과와 같았다. 또한, 증숙 공정 후에도 총 폴리페놀 함량 이 다소 증가하는 경향을 보였는데 이는 가열처리에 의해 내부 조직이 파괴되어 페놀성 화합물이 쉽게 추출되어 함량이 증가한 것으로 여겨진다(Lee 등, 2004). 따라서 증 숙을 통해 페놀성 화합물의 추출을 용이하게 한 후 볶음 공정을 거침으로써 총 폴리페놀 함량이 가장 증대된 것으 로 판단된다. 데침 처리구에서는 대조구에 비해 총 폴리페 놀 함량이 감소하였는데, 이는 데침에 조직 내의 폴리페놀 이 용출되어 함량이 감소한 것으로 여겨지며, 데쳤을 때 조리수로 용출되어 페놀성 화합물의 함량이 감소하였다 (Kim과 Lee, 2004)는 결과와 일치하였다.

폴리페놀계 화합물 중 하나인 플라보노이드는 자연식 물에 널리 분포되어 있는 천연항산화 물질로 항산화 활성 을 비롯하여 항염증, 항암효과 등 다양한 생리활성이 있다 고 보고되고 있다(Vijaya 등, 1995). 처리방법을 달리한 마늘 껍질 추출물의 총 플라보노이드 함량을 분석한 결과(Table 4), 증숙 후 볶음 처리구에서 $17.63 \mathrm{mg} / 100 \mathrm{~g}$ 으로 가장 높았 으며 30 분 볶음 처리구 $(11.05 \mathrm{mg} / 100 \mathrm{~g})$, 증숙 처리구 (6.69 $\mathrm{mg} / 100 \mathrm{~g})$, 대조구 $(3.68 \mathrm{mg} / 100 \mathrm{~g})$, 데침 처리구 $(3.43 \mathrm{mg} / 100$ g) 순으로 나타났다. 이는 Jo와 $\operatorname{Surh}(2016)$ 의 연구에서 다양 한 열처리 방법을 이용하여 마늘을 조리한 결과, 찌기와 로스팅 방법을 이용한 마늘의 플라보노이드 함량은 증가하 였고, 삶기 방법을 이용한 마늘의 플라보노이드 함량은 감 
Table 5. DPPH radical scavening ability of garlic peel treated by roasting, steaming, roasting after steaming and blanching

\begin{tabular}{cl}
\hline Processing method & $\begin{array}{c}\text { DPPH radical scavenging } \\
\text { ability (\%) }\end{array}$ \\
\hline Control & $57.45 \pm 0.83^{1) \mathrm{c} 2)}$ \\
Roasting & $65.54 \pm 2.74^{\mathrm{b}}$ \\
Steaming & $59.11 \pm 0.84^{\mathrm{c}}$ \\
Roasting after steaming & $81.28 \pm 0.76^{\mathrm{a}}$ \\
Blanching & $29.33 \pm 0.28^{\mathrm{d}}$ \\
\hline
\end{tabular}

${ }^{1)}$ Values are mean $\pm \mathrm{SD}$.

${ }^{2)}$ Means with different letters in the same column are significantly different by Duncan's multiple range test $(p<0.05)$.

소한 것으로 나타났다는 결과와 매우 유사하였다.

가공방법을 달리한 마늘껍질의 총 폴리페놀과 총 플라보 노이드 함량은 비슷한 경향을 보였는데, 두 성분간의 상관 계수는 $\mathrm{R}^{2}=0.9869$ 로 두 요인간에 높은 정의 상관관계를 보 였다. 따라서 총 폴리페놀 함량이 높은 시료는 총 플라보노 이드 함량도 비교적 높게 함유된 것으로 평가된다.

\section{$\mathrm{DPPH}$ 라디칼 소거활성}

처리방법에 따른 마늘껍질의 항산화 활성을 확인하기 위해 DPPH 라디칼 소거활성을 이용하였으며 그 결과는 Table 5와 같다. 증숙 후 볶음 처리구에서 $\mathrm{DPPH}$ 라디칼 소거활성이 $81.28 \%$ 로 가장 높았고, 다음으로 볶음 처리구 $65.54 \%$, 증숙 처리구 $59.11 \%$, 대조구 $57.45 \%$, 데침 처리구 $29.33 \%$ 순으로 높은 항산화 활성을 나타내었다. 증숙 후 볶음 처리구와 데침 처리구의 경우 약 2.7 배 정도의 활성 차이를 나타내었으며, 이는 총 폴리페놀 및 총 플라보노이 드 함량과 같은 경향을 나타내어 총 폴리페놀 및 총 플라보 노이드 함량이 높은 처리구에서 DPPH 라디칼 소거활성도 높게 나타났다. 이는 폴리페놀, 플라보노이드 함량은 $\mathrm{DPPH}$ 라디칼 소거활성과 밀접한 상관관계가 있어 항산화 성분이 증가하면 항산화 활성도 증가한다 $(\mathrm{Gu}$ 등, 2017)는 결과와 유사하였다. 이런 결과를 종합해보면, 마늘껍질을 증숙한 후 볶음처리를 하는 것이 항산화 성분, 항산화 활성 등 생리활성이 높아 기능성 소재로 활용하기에 바람직할 것으로 생각된다.

\section{요 약}

본 연구에서는 가공방법이 마늘껍질의 품질 특성에 미 치는 영향을 알아보고자 수행하였다. 색도 명도는 가공 공정을 거치면서 모두 낮아졌으며 적색도는 증숙 처리 시 높은 경향을 보였고 황색도는 볶음 처리 시 증가하였다.
피루브산 함량은 가공 공정을 거치면서 모두 증가하였는 데, 볶음 처리 시 높은 경향을 보였다. 총 폴리페놀 및 플라보노이드 함량, DPPH 라디칼 소거활성 또한 볶음 처 리구에서 전체적으로 높은 함량을 나타내어 증숙 처리보 다 볶음 처리 시 우수한 활성을 나타내는 것으로 나타났다. 결과를 종합해 볼 때 볶음처리가 마늘껍질의 항산화 증진 에 영향을 미치며, 특히 증숙 후 볶는 방법을 이용하였을 때 높은 항산화 활성을 나타내므로 마늘껍질의 가공방법 에 적합할 것으로 판단된다. 본 연구결과는 마늘껍질 활용 의 기초자료로 제공되어 향후 연구 수행에 도움을 줄 수 있을 것으로 판단된다.

\section{감사의 글}

본 논문은 농촌진흥청 연구사업(과제번호: PJ01263805) 의 지원에 의해 이루어진 것임.

\section{Conflict of interests}

The authors declare no potential conflict of interest.

\section{ORCID}

Ji Hyun Min https://orcid.org/0000-0003-4179-425X

\section{References}

Amerine MA, Ough CS. Methods for the Analysis of Musts and Wines. Wiley, New York, USA p 176-180 (1981)

AOAC. Official Methods of Analysis. 15th ed, Association of Official Analytical Chemists, Washington DC, USA, p 69-90 (1995)

Banerjee SK, Maulik SK. Effect of garlic on cardiovascular disorders: A review. Nutr J, 1, 1-14 (2002)

Blois MS. Antioxidant determinations by the use of a stable free radical. Nature, 181, 1199-1200 (1958)

Choi HK. A study on the antibacterial activity of garlic against Escherichia coli O157. J Korean Practical Arts Edu, 14, 159-167 (2001)

Chung HS, Park HS, Kim HS, Lee YG, Seong JH. Effect of ethanol leaching conditions on the properties of liqueur prepared from Citrus junos fruit peels. Korean J Food Preserv, 26, 194-200 (2019)

Gu YR, Kim SW, Son YW, Hong JH. Antioxidant activities of solvent extracts from different Glehnia Radix parts and their inhibitory effect against nitric oxide production in 
Raw 264.7 cell. Korean J Food Preserv, 24, 116-124 (2017)

Hwang JB, Ha JH, Park WS, Lee YC. Changes of component on green discolored garlic. Korean J Food Sci Technol, 36, 1-8 (2004)

Im HJ, Kim CY, Yoon KY. Production and characteristics of Cello-and Xylo-oligosaccharides by enzymatic hydrolysis of buckwheat hulls. Korean J Food Sci Technol, 48, 201-207 (2016)

Jo HR, Surh JH. Effects of cooking methods with different heat intensities on antioxidant activity and physicochemical properties of garlic. J Korean Soc Food Sci Nutr, 45, 1784-1791 (2016)

Kim D, Kim KH, Yook HS. Analysis of active components of giant black garlic. J Korean Soc Food Sci Nutr, 44, 1672-1681 (2015)

Kim HJ, Han CH, Kim NY, Lee EK, Lee KN, Cho HE, Choi YH, Chong MS. Effect of garlic extracts with extraction conditions on antioxidant and anticancer activity. Korean J Oriental Physiology Pathology, 24, 111-117 (2010)

Kim JA, Lee JM. Changes of chemical components and antioxidant activities in Hizikia fusiformis (Harvey) Okamura with blanching times. Korean J Food Cookery Sci, 20, 219-226 (2004)

Kim KJ, Do JR, Kim HK. Antimicrobial, antihypertensive and anticancer activities of garlic extracts. Korean J Food Sci Technol, 37, 228-232 (2005)

Kim RJ, Kang MJ, Lee SJ, Shin JH, Sung NJ. Physicochemical characteristics and antioxidant activities of fermented garlic husk. J Korean Soc Food Sci Nutr, 39, 1731-1738 (2010)

Ko MJ, Kwon HL, Chung MS. Optimum conditions for extracting flavanones from grapefruit peels and encapsulation of extracts. Korean J Food Sci Technol, 46, 465-469 (2014)

Koch HP, Lawson LD. Garlic: The science and therapeutic application of Allium sativum L. and related species, 2nd ed, Williams \& Wilkins, Baltimore, MD, USA, p 1-223 (1996)

Kwon YR, Youn KS. Physicochemical of burdock (Arctium lappa L) tea depending on steaming and roasting treatment. Korean J Food Preserv, 21, 646-651 (2014)

Lee GD, Yoon SR, Kim JO, Hur SS, Seo KI. Monitoring on the tea with steaming and drying process of germinated buckwheat. J Korean Soc Food Sci Nutr, 33, 212-217 (2004)

Ma SH, Kim GW, Son JY. Quality characteristics and antioxidant effects of Makgeolli with onion skin by Nuruk and Ipguk. Korean J Food Cook Sci, 35, 288-298 (2019)

Miron T, Shin I. Feigenblat G, Weiner L, Mirelman D, Wilchek M, Rabinkov A. A spectrophotometric assay for allicin, alliin, and alliinase (alliin lyase) with a chromogenic thiol: Reaction of 4-mercaptopyridine with thiosulfinates. Anal Biochem, 307, 76-83 (2002)

Moreno MIN, Isla MI, Sampietro AR, Vattuone MA. Comparison of the free radical-scavenging activity of propolis from several regions of Argentina. J Ethnopharmacol, 71, 109-114 (2000)

Nuutila AM, Puupponen-Pimia R, Aarni M, OksmanCaldentey KM. Comparison of antioxidant activities of onion and garlic extracts by inhibition of lipid peroxidation and radical scavenging activity. Food Chemistry, 81, 485-493 (2003)

Ruffin J, Hunter SA. An evaluation of the side effects of garlic as an antihypertensive agent. Cytobios, 37, 85-89 (1983)

Schwimmer S, Weston WJ. Onion flavor and odor, enzymatic development of pyruvic acid in onion as a measure of pungency. J Agric Food Chem, 9, 301-304 (1961)

Sharma KK, Sharma SP. Effect of onion and garlic on serum cholesterol in normal subjects. Mediscope, 22, 134-136 (1979)

Shin JH, Choi DJ, Chung MJ, Kang MJ, Sung NJ. Changes of physicochemical components and antioxidant activity of aged garlic at different temperatures. J Korean Soc Food Sci Nutr, 37, 1174-1181 (2008)

Shin SH, Kim MK. Effect of dried powders or ethanol extracts of garlic flesh and peel on antioxidative capacity in 16-month-old rats. J Nutr Health, 37, 633-644 (2004a)

Shin SH, Kim MK. Effect of dried powders or ethanol extracts of garlic flesh and peel on lipid metabolism and antithrombogenic capacity in 16-month-old rats. J Nutr Health, 37, 515-524 (2004b)

Son DY. Antiproliferation effects of ethanol extract of garlic peels on human cancer cell lines. Korean J Food Preserv, 24, 289-293 (2017)

Song SB, Ko JY, Kim JI, Lee JS, Jung TW, Kim KY, Kwak DY, Oh IS, Woo KS. Changes in physicochemical characteristics and antioxidant activity of adzuki bean and adzuki bean tea depending on the variety and roasting time. Korean J Food Sci Technol, 45, 317-324 (2013)

Vijaya K, Ananthan S, Nalini R. Antibacterial effect of theaflavin, polyphenon 60 (Camellia sinensis) and Euphorbia hirta on Shigella spp. - A cell culture study. J Ethnopharmacol, 49, 115-118 (1995) 